\title{
The Effect of Role-Playing Method on Student's Confidence in Indonesian Language Subjects
}

\section{Pengaruh Metode Bermain Peran terhadap Kepercayaan Diri Siswa pada Mata Pelajaran Bahasa Indonesia}

\author{
Ayu Tusaroh*, Juhji Juhji \\ Universitas Islam Negeri Sultan Maulana Hasanuddin Banten, Indonesia
}

The purpose of this study was to determine the effect of the method of playing role on student confidence in Indonesian subjects. The quasi-experimental method is used as a research method with the Non-Equivalent Control Group Design research design. The population of all students in primary school state of Cilaku. Samples were taken as many as 48 students, from the VA class of 24 students as the control class and from the VB class of 24 as the experimental class. The data analysis technique used is determining the average, calculating the standard deviation, normality test, homogeneity test and t-test. The results showed that the variable of students 'confidence using the role playing method obtained an average posttest score of 78.33 while the results of students' confidence using conventional learning obtained an average posttest score of 66.17. Then the hypothesis test is performed which shows the results of $t$ count 4.09 and $t_{\text {table }}=2.074$ with $n-2=24-2=22$ and a significance level of 0.05. Based on the $\mathrm{t}_{\text {count }}>\mathrm{t}_{\text {test }}$ criteria $\mathrm{Ha}$ is accepted and $\mathrm{Ho}$ is rejected. Thus it can be concluded that the role playing method influences students' confidence in Indonesian subjects.

Edited by:

Moch. Bahak Udin By Arifin

Reviewed by:

Mu'alimin

*Correspondence:

Ayu Tusaroh

ayutusaroh@gmail.com

Received: 2 Januari 2020

Accepted: 10 Februari 2020

Published: 30 April 2020

Citation:

Tusaroh A and Juhij J (2020) The

Effect of Role-Playing Method on

Student's Confidence in Indonesian

Language Subjects.

Madrosatuna: Journal of Islamic

Elementary School. 4:1.

doi: 10.21070/madrosatuna.v4i1.37

Keywords: Role Playing Method, Self Confidence

\begin{abstract}
ABSTRAK
Tujuan penelitian ini untuk mengetahui pengaruh metode bermain peran terhadap kepercayaan diri siswa pada mata pelajaran ahasa Indonesia. Metode kuasi eksperimen dijadikan sebagai metode penelitian dengan desain penelitian Non-Equivalent Control Group Design. Populasi seluruh siswa Sekolah Dasar Negeri Cilaku. Sampel yang diambil sebanyak 48 siswa, dari kelas VA yang berjumlah 24 siswa sebagai kelas kontrol dan dari kelas VB yang berjumlah 24 sebagai kelas eksperimen. Teknik analisi data yang digunakan adalah menentukan ratarata, menghitung simpangan baku, uji normalitas, uji homogenitas dan uji-t. Hasil penelitian menunjukan bahwa variabel kepercayaan diri siswa dengan menggunakan metode bermain peran memperoleh rata-rata nilai posttest 78,33 sedangkan hasil kepercayaan diri siswa dengan menggunakan pembelajaran konvensional memperoleh rata-rata nilai posttest 66,17 . Selanjutnya dilakukan uji hipotesis yang menunjukkan hasil $\mathrm{t}_{\text {hitung }} 4,09$ dan $\mathrm{t}_{\text {tabel }}=2,074$ dengan $\mathrm{n}-2$ $=24-2=22$ dan taraf signifikan 0,05. Berdasarkan kriteria pengujian $\mathrm{t}_{\text {hitung }}>\mathrm{t}_{\text {tabel }}$ maka $\mathrm{H}_{a}$
\end{abstract}


diterima dan $\mathrm{H}_{O}$ ditolak. Dengan demikian dapat disimpulkan bahwa metode bermain peran berpengaruh terhadap kepercayaan diri siswa pada mata pelajaran Bahasa Indonesia. 


\section{PENDAHULUAN}

Bahasa Indonesia adalah alat komunikasi yang dipergunakan oleh masyarakat Indonesia untuk keperluan sehari-hari, misalnya belajar, bekerja sama dan berinteraksi Isah (2009) . Sebagai makhluk sosial, manusia berinteraksi, berkomunikasi dengan manusia lain dengan menggunakan bahasa sebagai media, baik berkomunikasi menggunakan bahasa lisan, juga berkomunikasi menggunakan bahasa tulisan Sutanto (2012). Manusia memerlukan orang lain untuk berkomunikasi dalam kehidupannya. Hidup manusia berada di lingkungan yang menjadi tempat untuk bergaul, baik di lingkungan rumah, sekolah, dan juga masyarakat. Oleh karena itu manusia perlu memiliki sikap, perasaan, keterampilan serta perilaku, salah satunya kepercayaan diri untuk menunjang penerimaan lingkungan terhadapnya.

Kepercayaan diri membuat manusia merasa nyaman berada di lingkungan tempat individu tersebut berada sehingga individu merasa yakin terhadap suatu langkah dan keputusan yang diambilnya guna mencapai tujuan yang diharapkannya. Kepercayaan diri sangat diperlukan siswa untuk menciptakan sikap belajar yang baik sehingga dapat mencapai prestasi belajar yang optimal.

Pada permasalahan seperti ini biasanya berdampak pada rendahnya kepercayaan diri siswa. Permasalahan kepercayaan diri siswa ini tentunya berdampak pula terhadap prestasi belajar siswa yang cenderung akan menurun. Hal ini ditandai dengan saat melakukan aktivitas-aktivitas yang mengukur kemampuan penguasaan materi, siswa akan merasa malu serta tidak percaya diri akan kemampuan yang dimilikinya. Karena pada saat berlangsungnya pembelajaran, siswa hanya duduk, diam dan memperhatikan. Yang kenyataannya sebagian besar kegiatan belajar mengajar menjadi tidak efektif.

Berdasarkan observasi, ada beberapa penyebab kurangnya kepercayaan diri siswa pada mata pelajaran Bahasa Indonesia, diantaranya: saat pembelelajaran berlangsung guru tidak memberi kesempatan kepada siswa untuk bertanya jika ada yang belum dipahami mengenai materi yang disampaikan guru yang menjadikan siswa merasa takut bertanya, mengungkapkan pendapat, dan saat mengerjakan soal Bahasa Indonesia. Karena pada kenyataannya banyak siswa yang lebih baik menunggu jawaban temanya daripada harus mengerjakan secara langsung dan menyerahkan jawabannya sendiri. Siswa selalu menutupi jawabannya dan tidak ingin terihat ketika diperiksa oleh guru. Selain itu, siswa tidak berani untuk mengemukakan jawabannya dengan alasan takut salah. Sedangkan orang tua mempunyai harapan besar kepada anak agar tumbuh dengan rasa percaya diri yang tinggi dengan merasa yakin akan kemampuan diri sendiri dan tidak bergantung kepada orang lain Utami and Hanafi (2018).

Salah satu cara yang dipakai untuk membantu siswa meningkatkan kepercayaan diri adalah melalui metode bermain peran. Penggunaan beberapa metode pembelajaran dapat digunakan untuk menarik perhatian, minat, dan kepercayaan diri siswa. Metode pembelajaran berfungsi untuk membantu siswa memperoleh kemudahan dalam memahami materi. Salah satu metode pembelajaran yang dianggap dapat meningkatkan kepercayaan diri siswa yaitu metode bermain peran. Untuk itu guru mencoba menggunakan metode bermain peran ini untuk meningkatkan kepercayaan diri siswa, karena melalui metode bermain peran ini siswa diharapkan partisipasi dalam mengikuti pelajaran di dalam kelas dan kepercayaan diri siswa meningkat.

Metode adalah cara kerja Hujaemah et al. (2019) yang bersistem untuk memudahkan pelaksanaan suatu kegiatan guru mencapai tuan yang ditentukan Iskandar and Sunendar (2011). Metode adalah cara yang digunakan untuk mengimplementasikan rencana yang sudah disusun dalam kegiatan nyata agar tujuan yang telah disusun tercapai secara optimal Majid (2013). Dari beberapa pengertia di atas, dapat disimpulkan bahwa medote adalah cara yang dilakukan guru untuk memberikan pembelajaran kepada siswa secara aktif, efektif dan efisien untuk mencapai tujuan. Sedangkan pembelajaran merupakan kegiatan terencana yang mengkondisikan atau merangsang seseorang agar bisa belajar dengan baik agar sesuai dengan tujuan pembelajaran Majid (2013).

Metode pembelajaran dapat diartikan sebagai cara yang digunakan pendidik untuk mengimplementasikan rencana pelaksanaan pembelajaran yang sudah disusun dalam bentuk kegiatan nyata dan praktis untuk mencapai tujuan pembelajaran yang telah ditentukan. Pengertian ini mendorong pendidik untuk dapat menentukan metode yang tepat yang akan digunakan dalam proses pembelajaran yang dilakukan agar terdapat ketepatan dalam penyampaian materi pembelajarn sehingga dapat diserap secara baik oleh peserta didik Juhji (2018).

Metode bermain peran yaitu cara mendramatisasikan tingkah laku Aini (2018), Bellina (2019) dalam hubungannya dengan masalah-masalah social dengan tujuan agar peserta didik dapat menghayati dan menghargai perasaan orang lain, dapat belajar membagi tanggungjawab, dan dapat mengambil keputusan secara spontan Juhji (2018).

Bermain peran adalah suatu penguasaan bahan-bahan pelajaran melalui pengembangan imajinasi dan penghayatan siswa. Pengembangan dan penghayatan imajinasi dilakukan siswa dengan memerankan diri sebagai tokoh hidup atau benda mati. Permainan ini pada umumnya dilakukan lebih dari satu orang. Bergantung pada apa yang diperankan. Pada strategi role playing, titik tekannya terletak pada keterlibatan emosional dan pengamatan indera ke dalam suatu situasi permasalahan yang secara nyata dihadapi. Siswa diperlakukan sebagai subjek pembelajaran yang secara aktif melakukanpraktik-praktik berbahasa (bertanya atau menjawab) bersama teman-temannya pada situasi tertentu Huda (2014) .

Kepercayaan diri merupakan suatu keyakinan dan sikap atas kemampuan untuk menerima diri sendiri secara apa 
adanya. Baik positif maupun negative Mildawani (2014). Kepercayaan diri merupakan suatu keyakinan dalam jiwa manusia bahwa tantangan hidup harus dihadapi dengan berbuat sesuatu. Kepercayaan diri itu lahir dari kesadaran bahwa jika memutuskan untuk melakukan sesuatu, sesuatu itu pula harus dilakukan. Kepercayaan diri itu akan datang dari kesadaran seorang individu bahwa ia memiliki tekad untuk melakukan apapun, sampai tujuan yang ia inginkan tercapai.

Rasa percaya diri adalah suatu keyakinan seorang terhadap segala aspek kelebihan yang dimilikinya dan keyakinan tersebut membuatnya merasa mampu untuk bisa mencapai berbagai tujuan di dalam hidupnya. Jadi, dapat dikatakan bahwa seseorang yang memiliki kepercayaan diri akan optimis dalam melakukan semua aktivitasnya.siswa yang memiliki kepercayaan diri akan mampu mengetahui kelebihan yang dimilikinya. Siswa tersebut menyadari, kalau segala kelebihan yang dimiliki tidak dikembangkan, maka akan menjadi sia-sia dan tidak ada artinya. Sebaliknya, kalau kelebihan yang dimilikinya mampu dikembangkan dengan optimal maka akan mendatangkan kepuasan sehingga pada gilirannya akan menumbuhkan kepercayaan diri yang lebih besar lagi Mildawani (2014). Dapat disimpulkan bahwa rasa percaya diri merupakan sikap yakin dan percaya terhadap diri dan akan merasa mampu menyelesaikan suatu pekerjaan, masalah dan berani mengambil keputusan.

Pentingnya memiliki kepercayaan diri dalam pembelajaran bahasa Indonesia adalah siswa dapat mengaktualisasikan diri. Aktualisasi diri adalah kemampuan seseorang untuk menemukan dan mengembangkan potensi yang dimiliki. Kepercayaan diri merupakan aspek yang sangat penting bagi seseorang untuk dapat mengembangkan potensinya. Jika seseorang memiliki bekal percaya diri yang baik, maka individu tersebut akan dapat mengembangkan potensinya. Namun jika seseorang memiliki kepercayaan diri rendah, maka individu tersebut cenderung menutup diri, mudah frustasi ketika menghadapi kesulitasn, canggung dalam menghadapi orang dan sulit menerima realita dirinya.

Dengan kepercayaan diri saat maju didepan kelas, dapat meningkatkan keberanian siswa dalam menjawab pertanyaan. Selain itu pembelajaran bahasa Indonesia dapat meningkatkan komunikasi dengan baik, memiliki ketegasan, mempunyai penampilan diri dengan baik, dan mampu mengendalikan perasaan. Memiliki kepercayaan diri yang tinggi dalam diri siswa dapat membantu mencapai prestasi dan hasil belajar yang lebih baik lagi. Anak yang ragu terhadap kemampuan diri sendiri/ tidak percaya diri saat pembelajaran bahasa Indonesia biasanya kurang dapat berbicara atau menyampaikan pesan kepada orang lain. Dengan bagitu akan terjadi proses perubahan dalam diri siswa bukan hanya pada hasil belajar tetapi juga pada perilaku dan sikap siswa. Siswa yang memiliki kepercayaan diri rendah dalam pembelajaran bahasa Indonesia dapat dilihat dari adanya gejala-gejala yang tampak diantaranya ragu-ragu saat berbicara di depan kelas dan diam saat ditunjuk guru untuk maju di depan kelas.

Menumbuhkan kepercayaan diri haruslah diawali oleh diri sendiri. Hal ini menjadi penting dikarenakan hanya individu yang bersangkutanlah yang dapat mengatasi rasa kurang percaya diri yang sedang dialaminya. Beberapa hal yang dapat meningkatkan kepercayaan diri, ialah: a) Evaluasi diri secara objektif, b) Memberi penghargaan yang jujur terhadap diri, c) Positif thingking, d) Gunakan self-affirmation, e) Berani mengambil resiko, f) Belajar mensyukuri dan menikmati rahmat tuhan, g) Menetapkan tujuan yang realistis.

Mengetahui penyebab dari rendahnya kepercayaan diri merupakan awal dari upaya meningkatkan kepercayaan diri secara signifikan. Saat seseorang mengetahui penyebab ketidakpercayaan dirinya, ia akan dapat mengevaluasi diri melalui pemikiran positif, kata-kata yang memberikan semangat pada dirinya dan rasa syukur kepada Allah SWT. Ia merasa adanya dukungan emosional dan social sehingga mampu mengatasi masalah dan memperbaiki prestasi untuk meraih kepercayaan diri yang lebih tinggi.

Berdasarkan latar belakang diatas maka permasalahan yang dirumuskan dalam penelitian ini adalah: adakah pengaruh metode bermain peran terhadap kepercayaan diri siswa pada mata pelajaran bahasa Indonesia di kelas V SDN Cilaku? Tujuan dari penelitian ini yaitu untuk mengetahui adakah pengaruh metode bermain peran terhadap kepercayaan diri siswa pada mata pelajaran bahasa Indonesia.

\section{METODE PENELITIAN}

Dalam penelitian ini metode yang digunakan adalah metode eksperimen. Penelitian eksperimen adalah penelitian yang digunakan untuk mencari pengaruh perlakuan tertentu terhadap yang lain dalam kondisi yang terkendalikan Sugiyono (2013) . Dalam penelitian quasi eksperimen, peneliti tidak memilih secara random untuk menetapkan subjek yang dilibatkan dalam perlakuan. Dalam hal ini peneliti harus menggunakan kelompok atau kelas-kelas yang telah tersedia Satyosari (2016). Desain penelitian yang akan digunakan dalam penelitian ini yaitu desain Nonequivalent Control Group Desain, desain ini hampir sama dengan pretest-posttest control group desain, hanya pada desain ini kelompok eksperimen maupun kontrol tidak dipilih secara random Sugiyono (2013). Dalam desain ini melibatkan dua kelompok subjek, satu diberi perlakuan eksperimental (kelompok eksperimen) dan yang lain tidak diberi perlakuan (kelompok kontrol).

\section{HASIL DAN PEMBAHASAN}

Sebelum peserta didik menerima perlakuan, terlebih dahulu mereka diberikan pretest. Tujuannya untuk mengukur kemampuan awal kepercayaan diri peserta didik sebelum mendapatkan perlakuan. Dibawah ini merupakan grafik nilai pretest antara kelas kontrol dan kelas eksperimen.

Hasil perhitungan rata-rata, dan varians pretest antara kelas eksperimen dan kelas kontrol. 

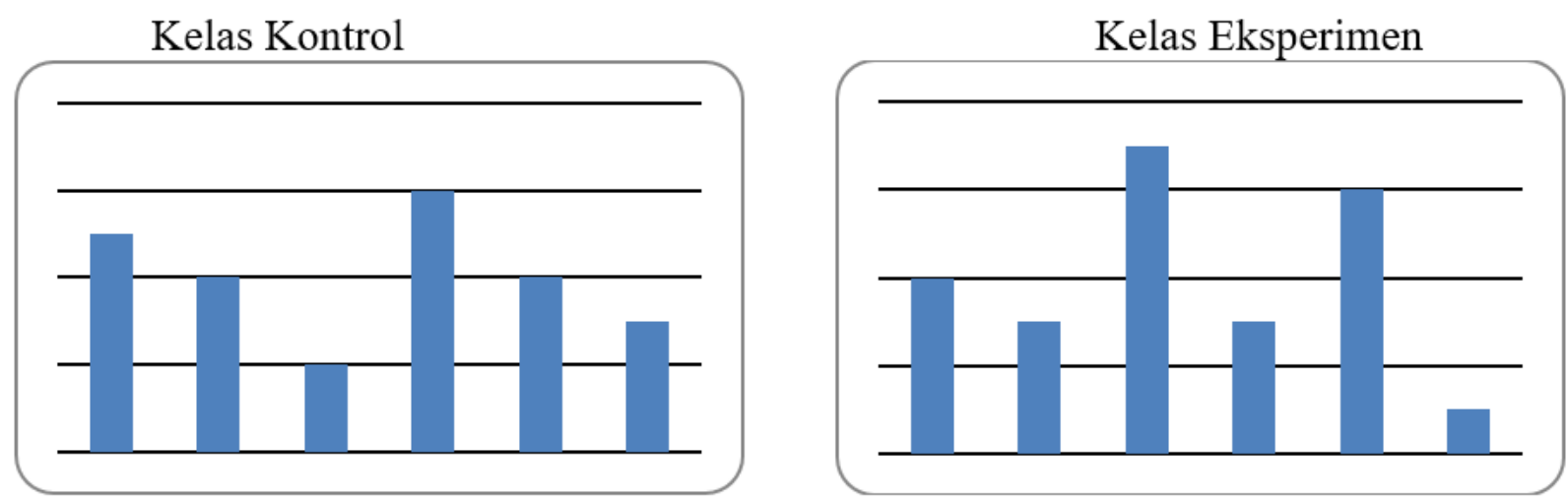

FIGURE 1 | Grafiknilai pretest kelas kontrol dan kelas eksperimen

TABLE 1 | Statistik Deskriptif Hasil Pretest Kelas Va Dan Vb

\begin{tabular}{lll}
\hline Statistik & Kelas Va (Kontrol) & Kelas Vb (Eksperimen) \\
Nilai minimum & 40 & 40 \\
Nilai maksimum & 80 & 80 \\
Rata-rata & 59,62 & 59,04 \\
Simpangan baku & 12,18 & 10,62 \\
\hline
\end{tabular}

Setelah kedua kelompok diberikan pretest dan telah dianggap sepadan, maka tahap selanjutnya adalah pemberian perlakuan atau treatment. Treatment ini dilakukan pada dua kelas, yaitu kelas eksperimen dan kelas kontrol. Treatment yang diberikan pada dua kelompok dibedakan pada penggunaan metode pembelajarannya, pada kelompok eksperimen menggunakan metode bermain peran, sedangkan kelompok kontrol tidak menggunakan metode bermain peran melainkan menggunakan pembelajaran secara konvensional.

Kemudian setelah kedua kelompok diberikan perlakuan atau treatment, dilakukan posttest untuk mengetahui apakah ada pengaruh atau tidak pembelajaran dikelas yang mengunakan metode bermain peran. Di bawah ini merupakan grafik hasil nilai posttest antara kelas kontrol dan kelas eksperimen.

Adapun hasil perhitungan statistic posttest kelas eksperimen dan kelas kontrol dapat dilihat pada tabel berikut:

\section{Uji Normalitas}

Uji normalitas ini dilakukan dengan menggunakan chi kuadrat $\left(\chi^{2}\right)$ dengan taraf signifikan 0,05, setelah dihitung chi kuadrat $\left(\chi^{2}\right)$, selanjutnya adalah membandingkan nilai chi kuadrat hitung dengan chi kuadrata tabel. Berdasarkan hasil analisis uji normalitas dapat dilihat pada tabel sebagai berikut:

Uji Homogenitas Pretest dan Posttest Kelas Eksperimen dan Kelas Kontrol

Uji homogenitas pretest dan posttest kelas eksperimen dan kelas kontrol diperoleh varians simpangan baku dan hasil analisis data tersebut dapat dilihat pada tabel sebagai berikut:

Berdasarkan data diatas, dapat disimpulkan bahwa data pretest dan posttest kelas eksperimen dan kelas kontrol homogen.

Uji Hipotesis
Pengujian hipotesis menggunakan uji t untuk dua sampel yang satu sama lain saling berhubungan, analisis data penelitian dapat dilihat pada tabel sebagai berikut:

Dengan taraf signifikan 0,05 dengan df $\mathrm{n}-2=24-2=22$ adalah 2,074. Karena to $>$ ttabel atau 4,09>2,074. Maka Ho ditolak dan Ha diterima yang berarti ada pengaruh metode bermain peran terhadap kepercayaan diri siswa pada mata pelajaran Bahasa Indonesia. Dari hasil analisis dapat diketahui $78 \%$ dipengaruhi oleh metode bermain peran, dan $22 \%$ dipengaruhi oleh faktor lain seperti kemampuan siswa, ketidakmampuan anak dalam mengaplikasikan metode.

Dapat disimpulkan bahwa perbedaan nilai posttest kelas eksperimen lebih tinggi dibandingkan dengan nilai posttest kelas kontrol. Sehingga ada pengaruh yang positif dari penggunaan metode bermain peran terhadap kepercayaan diri siswa pada mata pelajaran bahasa Indonesia.

\section{KESIMPULAN}

Berdasarkan hasil penelitian yang telah dilakukan beserta analisis data pengujian hipotesis dapat diambil kesimpulan bahwa : hasil akhir posttet diperoleh nilai rata-rata untuk kelas eksperimen 78,33 dan untuk kelas kontrol 66,17, maka hasil kepercayaan diri siswa dengan metode bermain peran lebih tinggi dari pada pembelajaran konvensional. Hal ini dapat dikatakan bahwa hasil kepercayaan diri siswa jauh lebih baik dengan diterapkannya metode bermain peran. Dan berdasarkan hasil uji hipotesis posttest kelas eksperimen dan kelas kontol didapatkan $\mathrm{t}_{\text {hitung }}=4,09$ lebih besar dari $\mathrm{t}_{\text {tabel }}$ dengan $\mathrm{t}_{\text {tabel }}=2,074$. Jadi $\mathrm{t}_{\text {hitung }}>\mathrm{t}_{\text {tabel }}$ atau 4,09>2,074. Dari 


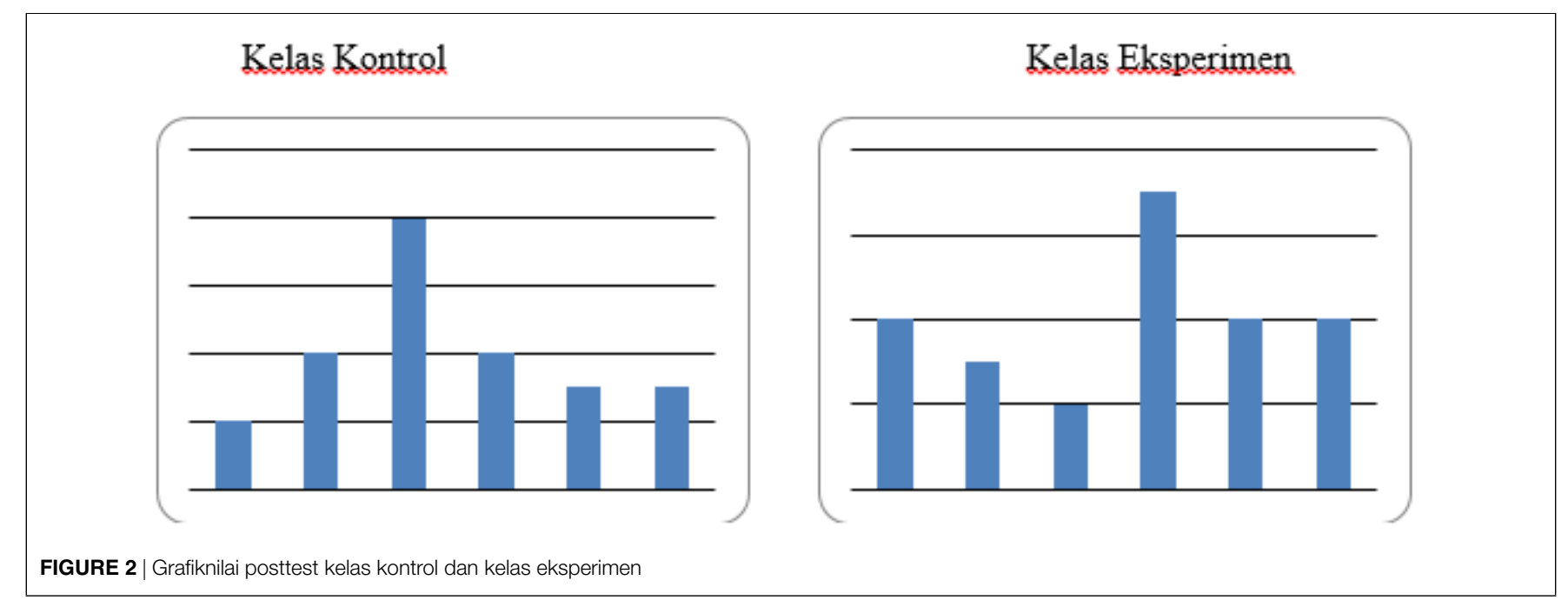

TABLE 2 | Statistik Deskriptif Hasil Posttest Kelas Eksperimen Dan Kelas Kontrol

\begin{tabular}{lll}
\hline Statistik & Kelas Va (kontrol) & Kelas Vb (eksperimen) \\
Nilai minimum & 43 & 63 \\
Nilai maksimum & 90 & 91 \\
Rata-rata & 66,17 & 78,33 \\
Simpangan Baku & 11,79 & 8,55 \\
\hline
\end{tabular}

TABLE 3 | Uji Normalitas Data Pretest Kelas Va dan Vb

\begin{tabular}{llll}
\hline Kelas & $\chi^{2}$ hitung & $\chi^{2 \text { tabel }}$ & keputusan \\
$\mathrm{Va}$ & 6,71 & 11,070 & Normal \\
$\mathrm{Vb}$ & 6,52 & 11,070 & Normal \\
\hline
\end{tabular}

TABLE 4 | Uji Normalitas Data Poattest Kelas Eksperimendan Kelas Kontrol

\begin{tabular}{llll}
\hline Kelas & $\chi^{2}$ hitung & $\chi^{2}$ tabel & keputusan \\
Va (kelas kontrol) & 9,25 & 11,070 & Normal \\
Vb (kelas eksperimen) & 6,96 & 11,070 & Normal \\
\hline
\end{tabular}

TABLE 5 | Hasil Uji Homogenitas

\begin{tabular}{lllllll}
\hline Nilai & Dk Pembilang & Dk Penyebut & Taraf signifikan & Fhitung & Ftabel & Keputusan \\
Pretest kelas Va dan Vb & 23 & 23 & 0,05 & 1,31 & 2,04 & Homogen \\
Posttest kelas Va dan Vb & 23 & 23 & 0,05 & 1,90 & 2,04 & Homogen \\
\hline
\end{tabular}

TABLE 6 | Hipotesis uji t

\begin{tabular}{lllll}
\hline & rata-rata & to & ttabel & Simpulan \\
24 & 78,33 & 4,09 & 2,074 & Ho ditolak dan Ha diterima \\
24 & 66,17 & 4,09 & 2,074 & Ho ditolak dan Ha diterima \\
\hline
\end{tabular}

hasil analisis dapat diketahui $78 \%$ dipengaruhi oleh metode bermain peran, dan $22 \%$ dipengaruhi oleh faktor lain yaitu kemampuan siswa, ketidakmampuan anak dalam mengaplikasikan metode. Karena itu dinyatakan bahwa dapat pen- garuh yang signifikan terhadap kepercayaan diri siswa menggunakan metode bermain peran dalam mata pelajaran Bahasa Indonesia.

\section{REFERENCES}

Aini, N. (2018). Penerapan Metode Bermain Peran Mata Pelajaran Bahasa Indonesia Pada MI Kelas 2. Madrosatuna: Journal of Islamic Elementary School 2, 1-4.

Bellina, O. (2019). Penerapan bermain peran untuk meningkatkan keterampilan sosial dan keterampilan berkomunikasi siswa tk. Jurnal Dinamika Manajemen Pendidikan 4, 60-64. doi: http://dx.doi.org/10.26740/jdmp.v4n1.p60-64.

Huda, M. (2014). Model-Model Pengajaran dan Pembelajaran (Yogyakarta: Pustaka Pelajar).

Hujaemah, E., Saefurrohman, A., and Juhji, J. (2019). Pengaruh penerapan model 
snowball throwing terhadap hasil belajar ipa di sekolah dasar. Muallimuna: Jurnal Madrasah Ibtidaiyah 5, 23-32.

Isah, C. (2009). Pembelajaran Bahasa Indonesia (Jakarta: DEPAG RI).

Iskandar, W. and Sunendar, D. (2011). Strategi Pembelajaran Bahasa (Bandung: PT. Remaja Rosdakarya).

Juhji, J. (2018). Model Pembelajaran IPA untuk Calon Guru SD/MI (Serang: CV. Media Madani).

Majid, A. (2013). Strategi Pembelajaran (Bandung: PT. Remaja Rosdakarya).

Mildawani, T. S. (2014). Membangun Kepercayaan Diri (Jakarta: Lestari Kiranatama).

Satyosari, P. (2016). Metode Penelitian Pendidikan Pengembangan (Jakarta: Prenada Media Group).

Sugiyono (2013). Metode Penelitian Pendidikan: Pendekatan Kuantitatif Kualitatif, dan R\&D (Bandung: Alfabeta).

Sutanto, A. (2012). Teori Belajar dan Pembelajaran di Sekolah Dasar (Jakarta: Kencana Prenada Media Group).
Utami, R. W. T. and Hanafi, M. (2018). Pengaruh Metode Bermain Peran Ter hadap Peningkatan Percaya Diri Pada Anak Usia Pra Sekolah (4-5 Tahun) di Pendidikan Anak Usia Dini Insan Harapan Klaten. Jurnal Keperawatan Soedirman 12, 84-84. doi: 10.20884/1.jks.2017.12.2.694.

Conflict of Interest Statement: The authors declare that the research was conducted in the absence of any commercial or financial relationships that could be construed as a potential conflict of interest.

Copyright (c) 2020 Tusaroh and Juhji. This is an open-access article distributed under the terms of the Creative Commons Attribution License (CC BY). The use, distribution or reproduction in other forums is permitted, provided the original author(s) and the copyright owner(s) are credited and that the original publication in this journal is cited, in accordance with accepted academic practice. No use, distribution or reproduction is permitted which does not comply with these terms. 